\title{
The Effectiveness of the Early Childhood Supplementary Feeding Program (PAUD) in Bantul Regency
}

\author{
Dewi Amanatun Suryani ${ }^{1}$, Purwanto ${ }^{2}$, Sri Puryono ${ }^{3}$, Teuku Afrizal ${ }^{4}$, Hartuti Purnaweni ${ }^{5}$ \\ \{dewiamanatunsuryani@unisayogya.ac.id ${ }^{1}$ \} \\ Universitas Diponegoro, Indonesia ${ }^{1,2,3,4,5}$
}

\begin{abstract}
The Indonesian government's target in implementing the agenda of Goal 2 of the Sustainable Development Goals (SDGs) by 2030 includes ending all forms of malnutrition. Rikesda data in 2018 shows that as many as $3.9 \%$ of children under the age of five are malnourished. As an effort to implement the program in the regions, the Bantul Regency Government has issued a policy through Regent Regulation Number 5 of 2015 concerning General Guidelines for the Implementation of the Early Childhood Supplementary Food Provision Program (PAUD) and the Under Five Years Integrated Service Post (Posyandu) however there are still 4,773 toddlers are stunted. The research method in this study uses a quantitative approach with random sampling of 212 respondents. The results showed that $75.5 \%$ of respondents stated that the program was implemented effectively. Based on context indicators, $62.3 \%$ of respondents stated that they were effective, and based on the input indicators, $62.3 \%$ stated that they were effective. Based on process indicators $71.7 \%$ of respondents said it was effective, and based on the output indicators $58.5 \%$ of respondents said it was effective. The factor that hinders effectiveness is the total coverage of PAUD that cannot be fulfilled due to budget constraints. Recommendations from this study are improvements in the budgeting system, provision of standard implementation guidelines, involvement of stakeholders and the involvement of Puskesmas intensively in monitoring the development of children's nutritional status.
\end{abstract}

Keywords: The Effectiveness, Supplementary Feeding Program, SDGs

\section{Introduction}

Toddler period is a critical period during which the process of physical growth, psychomotor development, mental and social development is developing rapidly. Under nutrition in children under five that is not immediately addressed will develop into malnutrition. The impact caused by malnutrition is not only physical disturbances but also affects intelligence and productivity as adults. Generally, nutritional problems are caused by two factors, namely direct factors and indirect factors. The direct factors affecting nutritional status are food intake (energy and protein) and comorbidities (infections). Meanwhile, the indirect factors are knowledge level, education level, income level, parenting style, socioculture, food availability, health services and environmental factors [1]. The government has made efforts to improve nutrition problems by providing Recovery Supplementary Food, hereinafter referred to as PMT-P for infants and toddlers. The government's efforts are in line with the target of implementing the SDGs Goal 2 agenda, namely by 2030, ending all forms of 
malnutrition, including the achievement of the internationally agreed targets in 2025 on malnutrition and neglect in children under five, and addressing nutritional needs for adolescents. daughters, pregnant and lactating women, and the elderly [2].

Several studies have shown that the implementation of PMT programs in various regions is less effective. The implementation of the PMT-children under five at Puskesmas Mungkid Magelang has not been able to be implemented in accordance with the guidelines and technical guidelines set by the Ministry of Health. Especially in terms of planning the PMTtoddler program targets. The nutritional status of children under five has improved although there are still many malnutrition statuses [3]. From the input aspect, implementation guidelines are not well distributed, infrastructure and funding are also lacking. Meanwhile, in terms of process, storage and transportation are still inadequate. As for the monitoring process, monitoring is still lacking. In terms of output, there are still targets inaccuracy [4]. The results showed that there was no difference in the nutritional status of children under five [5].

The implementation of the PMT program in Bantul Regency refers to the Regent Regulation Number 5 of 2015 concerning General Guidelines for the Implementation of the Early Childhood Supplementary Food Supplying Program (PAUD) and the Under Five Years Integrated Service Post (Posyandu). Program implementation is coordinated by the Village Community Empowerment Planning Agency (DPPKBPMD) of Bantul Regency. Before becoming a national program, the Regent of Bantul took the initiative to give a pair of chickens to each elementary school child to be raised. Chicken products in the form of eggs are expected to provide additional nutritional adequacy for children.

The Bantul Regency Government then realized that the fulfillment of nutrition was more effectively given from a toddler. However, the effectiveness of this program has never been evaluated. Referring to the results of data collection by the Bantul District Health Office (Dinkses) in the last three years, the percentage of children under five with stunting has decreased in succession from $10.98 \%$ in 2016 , then the percentage has decreased by $0.57 \%$ to 10.41 in 2017 and a year then able to be reduced to $9.7 \%$. However, in terms of quantity, this figure is still high. A total of 4,773 out of 48,553 children under five are still stunted. If it is related to the poverty rate in Bantul Regency of $12.92 \%$ [6], toddlers belonging to poor families are increasingly vulnerable to experiencing malnutrition or stunting. The purpose of evaluating the implementation of the early childhood supplementary feeding program (PAUD) in Bantul Regency is to obtain a comprehensive and credible evaluation of program implementation and provide policy recommendations for program implementation.

Effectiveness is an achievement/success of an activity or activity carried out by a person or group of people according to a predetermined plan through the empowerment of all owned resources, both human resources and funding resources. To determine the effectiveness of the program, it is necessary to evaluate. James P. Lester and Joseph Stewart stated that policy evaluation is intended to test the suitability of policy results with the objectives to be achieved [7] Policy evaluation is an activity to determine implementation and then evaluate the course of a policy whether the policy has been implemented properly or not. The purpose of the evaluation is to find out whether the policy is feasible to continue or not [8]. Evaluation aims to provide information to policy makers about how their programs are running and to show what factors can be manipulated in order to achieve better results, to then provide new policy alternatives or simply other means of implementation. Based on Samodra [9] explanation, the information obtained from policy evaluation can be used to improve ongoing programs and even provide information on factors that can be manipulated. The results of the evaluation can be used to avoid programs that harm the community and determine the sustainability of the program in the future. If the results of the program evaluation show that there are things in the 
program that need to be changed, then decision makers should take them seriously. This means that they must have new ideas to improve the program, so that the program can avoid failure and can achieve the desired goals.

The definition of program evaluation according to Cronbach and Stufflebeam is an effort to provide information to be conveyed to decision makers [10]. Thus, program evaluation is a process of collecting scientific data or information whose results can be used as consideration for decision makers in determining policy alternatives. Program Evaluation Objectives for: a). Shows the contribution of the program to the achievement of organizational goals. The results of this evaluation are important for developing the same program elsewhere. b). Make decisions about the sustainability of a program, whether the program needs to be continued, improved or stopped [11].

According to Kaufman and Thomas in Arikunto [10] the evaluation model is divided into eight, namely: a. Goal Oriented Evaluation Model. The evaluation model put forward by Tyler is a goal-oriented evaluation, which is an evaluation model that emphasizes a review of the objectives from the start of the activity and takes place continuously. b. Goal Free Model. The model proposed by Scriven explains that the work procedure should not be too detailed if it emphasizes evaluation on goal achievement. c. Formative-Summative Evaluation Model, the model proposed by Scriven suggests two kinds of evaluation, namely formative (carried out during the program) and summative evaluation (carried out after the program ends). The formative-summative evaluation model is suitable for evaluating processing programs. Formative evaluation can be carried out at a part of the activity, while summative evaluation is carried out at the end of the program. d. Consideration Description Model, the evaluation model put forward by Stake emphasizes two steps of evaluation work, namely, description, then based on the results of the description the evaluator makes a consideration of comparing it with the expected conditions. Stake explained that three things were described, namely context, process and results. e. The CSE-UCLA Evaluation Model, it can be explained that the evaluation in this model focuses on four stages of the process, namely: planning, process, summative and formative. f. CIPP Evaluation Model, with this model directing the target object of its evaluation to the process and input to the results. g. The Gap Evaluation Model, a model proposed by Malcolm Provus, is a gap model that can be used to evaluate all types of programs. The basis for program evaluation is to assess the gap. In this study, the evaluation of the Early Childhood Supplementary Feeding program used the CIPP model, in which researchers conducted evaluations from the context of the success of achieving goals, input measured based on improvement in development and knowledge, processes measured based on planning to involvement of stakeholders, and measured results. based on the achievements of the program implementation. In addition, this evaluation describes the program implementation's perceptions of program success.

\section{Methodology}

This research uses quantitative research methods. Quantitative research methods can be defined as a research method based on the philosophy of positivism, used to research on a particular population or sample, and data collection using instruments. research, data analysis is quantitative / statistical, with the aim of testing the hypothesis that has been set. This method is called the positivistic method because it is based on the philosophy of positivism. This method is a scientific method because it has met scientific principles, namely concrete/empirical, objective, measurable, rational and systematic [12]. Margono explained 
that quantitative research is a study that mostly uses the logic of the verification hypothesis that starts with deductive thinking to derive the hypothesis then carries out testing in the field and the conclusion or hypothesis is drawn based on empirical data [13]. The research respondents consisted of 212 Early Childhood Education Institutions in Bantul Regency from 1294 PAUD institutions. The research period was carried out from February to June. Types of data include primary and secondary data. The data collection technique was carried out by distributing questionnaires and various document sources, including reports, regulations and documentation. The equipment used in data collection in this study were questionnaire sheets, mobile phones and laptops to find and record secondary data. Research variables include independent variables, namely the effectiveness of the implementation of the supplementary feeding program for early childhood. Dependent variables include content, input, process, and output. The data measurement technique was performed using a linkert scale with a scale of 15 to measure from less-very efectivness. The data analysis technique used inferential statistics. The analysis prerequisite test used in this study is the normality test, simple linear analysis and the prerequisite regression test.

\section{Discussion}

The evaluation of the PMT PAUD program is carried out comprehensively including content, input, process, and output or in other terms, namely system evaluation. The effectiveness of the program can be seen from the following criteria:

\subsection{Content}

The program effectiveness based on the intended content is the achievement of the following objectives: a. increasing the adequacy of students' nutritional intake through additional food; $b$. increase physical endurance and attendance of students in participating in learning activities; c. increase the knowledge and behavior of students for nutritious local food, implementing Clean and Healthy Living Behaviors (PHBS) and Clean and Healthy Environment (LBS); d. increasing community participation in utilizing and procuring local food; e. increase public awareness and participation in efforts to improve student nutrition, agricultural production, community income and family welfare; f. reduce absenteeism and increase children's attention and ability in the learning process in class; g. educate children to always like traditional food and local food / snacks; and h. increase the understanding of parents of students, teachers, school boards and the community about the importance of PMTPAUD. The results of the measurement of the program implementation content showed that as many as $86.8 \%$ stated that it was very effective as can be seen in the following figure 1 .

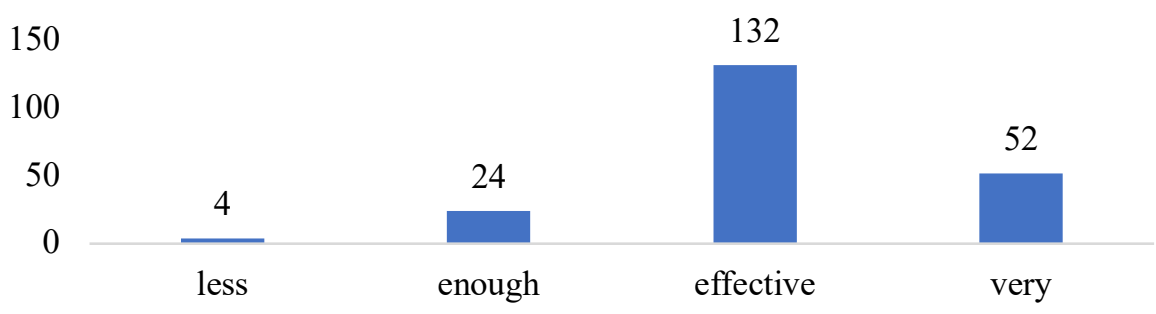

Fig. 1. Content Variables. 
Likewise, from the institutional report submitted to the PPKBPMD, it is stated that the benefits of the program include providing additional nutrition to students, with adequate nutritional intake, the presence of students in teaching and learning activities becomes more optimal, reducing expenditure. institutions in terms of providing additional food due to receiving assistance from the government, providing stimulus to parents/guardians about the importance of nutritious food for school age children, introducing children to nutritious local food products, and teaches a clean and healthy lifestyle. Children wash their hands with soap and throw garbage in its place.

\subsection{Input}

The result of measuring the effectiveness based on program input was $84.9 \%$ of respondents considered the program to be effective. Of the total budget received by PAUD institutions, $60 \%$ stated that it was effective and involved stakeholders, so $71.7 \%$ said it was effective and $9.4 \%$ of respondents said it was very effective. Supporting data from this assessment is taken from a sample of the PAUD institution's Annual Report which states that the implementing structure includes elements of the PKK, parents of students, and the hamlet. Matters that are still obstacles in its implementation include the budget received behind schedule, the limited amount of available budget that does not match the purchase price of foodstuffs, lack of knowledge of interesting and varied snack menus, lack of knowledge of nutritional value standards and dosages. should be given to the child.

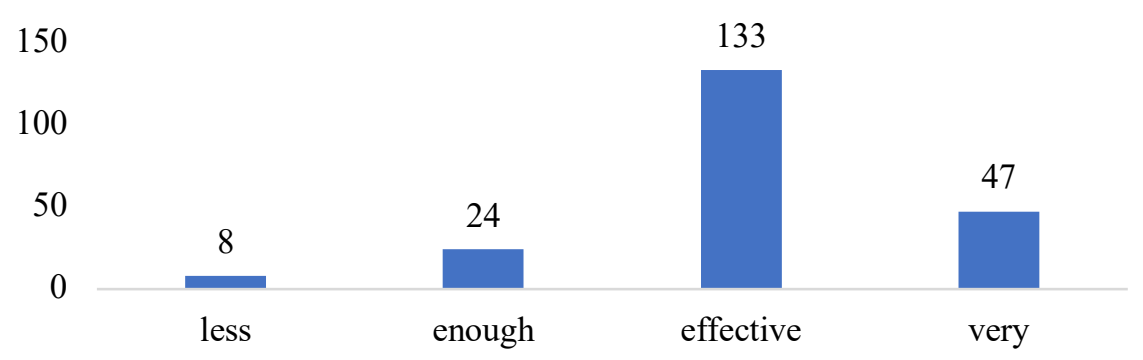

Fig. 2. Input Vvariables.

\subsection{Process}

Referring to the results of the process measurement, namely planning to involvement of stakeholders as illustrated in table 3 below, $71.7 \%$ said it was effective and $9.4 \%$ of respondents said it was very effective. Thus, the program performance from the process side was effective. Supporting data from this assessment was taken from the sample TK Annual Report in 2018 which stated that the program implementation structure involved elements of the PKK, parents of students, and hamlets. Based on the results of interviews with the Head of the DPPKBPMD also stated that before the provision of TK funds submitted a PMT PAUD program planning proposal which is addressed to the PPKBPMD Office and a coordination meeting for activity planning or socialization is held for fund recipients 


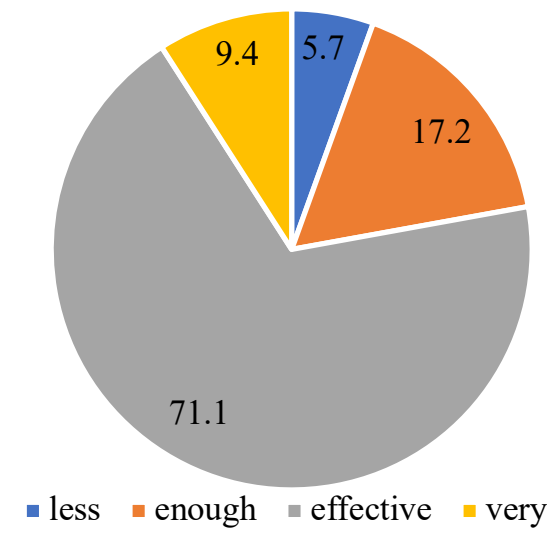

Fig. 3. Process Variables.

\subsection{Output}

Based on the measurement of children's body weight is classified as normal. The results of the comparison of the scales from the report between July and December showed that children experienced a weight gain of $18.6 \%$ while $79.1 \%$ remained normal, only $2.3 \%$ experienced a decrease. Even this condition needs to be studied further the factors causing it.

The annual report on program implementation also presents data on children's height increases. The height of children measured in July compared to December saw an increase of $18 \%$. The level of attendance for children based on the annual report presents data that children attend an average of $94.71 \%$ so that the PMT PAUD program has a significant effect on the level of attendance of children to school although further studies on this need to be done.

\section{Conclusion}

This program provides benefits in terms of content, namely for institutions to increase the budget for providing additional food intake, improve children's nutrition, teach children's character education through clean and healthy living habits, and introduce local food.

Barriers to input include receiving funds that are not on schedule, the lack of funds provided, and snack menus that are not fulfilled according to standard nutritional values. the program implementation process went well with socialization and coordination with the recipient institutions. In terms of results, it is evident that the child's weight gain is classified as normal. The PMT PAUD program increases children's attendance to school.

An effective early childhood Supplementary Feeding Program can be continued by considering the background scheme of the institutional capacity and income of the parents of students in participating in program fulfillment. The PPKBPMD office needs to collect data on the ability of parents and institutions and conduct further studies on the budgeting system with more attention to children who are more prone to malnutrition. The implementation guidelines are made as detailed as possible to make it easier for the Implementing Team to prepare administrative reports in accordance with the provisions. There is a need for additional 
information and knowledge for program implementers regarding the fulfillment of standards for balanced nutritional values and for processed snacks that are attractive to children. The involvement of the PKK and stakeholders can continue to be carried out as an effort to increase community participation in the process of formulating and implementing programs that encourage the growth of community self-help awareness. The importance of intensive community health center involvement in monitoring the development of children's nutritional status.

\section{References}

[1] F. F. Mulyadi, Suprayekti, Evaluasi Program. Jakarta: Lembaga Pengembangan UNJ, 2015.

[2] "https://www.sdg2030indonesia.org/page/10-tujuan-dua.".

[3] J. R. A. Butler et al., "Scenario planning to leap-frog the Sustainable Development Goals: An adaptation pathways approach," Clim. Risk Manag., vol. 12, pp. 83-99, 2016.

[4] H. V. S. Sugiarto and F. Fachrurrozie, "The determinant of accounting conservatism on manufacturing companies in Indonesia," Account. Anal. J., vol. 7, no. 1, pp. 1-9, 2018.

[5] A. S. R. Putri and T. Mahmudiono, "Efektivitas Pemberian Makanan Tambahan (PMT) Pemulihan Pada Status Gizi Balita di Wilayah Kerja Puskesmas Simomulyo, Surabaya," Amerta Nutr., vol. 4, no. 1, pp. 58-64, 2020.

[6] "https ://jogjapolitan.harianjogja.com/read/2020/01/15/511/1029462/diguyur-berbagai-bantuanangka-kemiskinan-di-bantul-cuma-turun-051-persen.” .

[7] D. D. V Kawengian and J. J. Rares, "Evaluasi Kebijakan Pencegahan dan Pemberantasan Perdagangan Manusia (Trafficking) Terutama Perempuan dan Anak di Kabupaten Minahasa Selatan Provinsi Sulawesi Utara," ACTA DIURNA Komun., vol. 4, no. 5, 2015.

[8] M. F. Akbar, "Evaluasi Kebijakan Program Pemberian Dana Bantuan Operasional Sekolah (Studi Kasus pada Sekolah Dasar di Kabupaten Mamuju Utara)," JAKPP (Jurnal Anal. Kebijak. Pelayanan Publik), pp. 47-64, 2016.

[9] P. Agus, P. Yuyun, and W. Samodra, "Evaluasi Kebijakan Publik, PT Raja Grafindo Persada, Jakarta, Cet." Pertama, 1994.

[10] S. Arikunto and C. S. A. Jabar, "Evaluasi Program Pendidikan, Cet," V, Jakarta Bumi Aksara, 2014.

[11] E. Mulyatiningsih, "Evaluasi Proses Suatu Program, Bumi Aksara,” Jakarta (3), pp. 36-41, 2011.

[12] Sugiyono, Metode Penelitian Kuantitatif, Kualitatif dan R\&D. Bandung: Alfabeta, 2006.

[13] A. Tanzeh, Pengantar Metode Penelitian. Teras. 2009. 